\title{
Handbook of Florida Water Regulation: Water Wells ${ }^{1}$
}

\author{
Michael T. Olexa, Luke D'Isernia, Laura Minton, Dulcy Miller, and Sarah Corbett ${ }^{2}$
}

\section{Preface}

This handbook is designed to provide an accurate, current, and authoritative summary of the principle Federal and Florida laws that directly or indirectly relate to agriculture. This handbook should provide a basic overview of the many rights and responsibilities that farmers and farmland owners have under both Federal and Florida laws as well as the appropriate contact information to obtain more detailed information. However, the reader should be aware that because the laws, administrative rulings, and court decisions on which this handbook is based are subject to constant revision, portions of this publication could become outdated at anytime.

Several details of cited laws are also left out due to space limitations.

This handbook is distributed with the understanding that the authors are not engaged in rendering legal or other professional advice, and the information contained herein should not be regarded as a substitute for professional advice. This handbook is not all inclusive in providing information to achieve compliance with the Federal and Florida laws and regulations governing water protection. For these reasons, the use of these materials by any person constitutes an agreement to hold harmless the authors, the Florida Cooperative Extension Service, the Institute of Food and Agricultural Sciences, and the University of Florida for any liability claims, damages, or expenses that may be incurred by any person as a result of reference to or reliance on the information contained in this handbook.

\section{Who Regulates Water Wells?}

Federal law does not directly regulate the construction of wells. However, because there is potential for groundwater pollution and other environmental damage through well structures, some of the broad federal environmental protection statutes might come into play. For example, seepage of hazardous waste from a polluted well that contaminated one of Florida's many aquifers would come under the Comprehensive Environmental Response, Compensation, and Liability Act's (CERCLA) cleanup provisions.

The Florida Department of Environmental Protection (DEP), through Chapter 373, Florida Statutes, Section 373.308, has delegated most of its

1. This is EDIS document FE603, a publication of the Food and Resource Economics Department, Florida Cooperative Extension Service, Institute of Food and Agricultural Sciences, University of Florida, Gainesville, FL. Published December 2005. Please visit the EDIS website at http://edis.ifas.ufl.edu.

2. Michael T. Olexa, Professor, Food and Resource Economics Department, Florida Cooperative Extension Service, Institute of Food and Agricultural Sciences, University of Florida, Gainesville, FL; Director, Agricultural Law Center, University of Florida, Gainesville, FL; and Chair, Agricultural Law Committee of The Florida Bar. Luke D'Isernia, former student (graduated cum laude in 2005), Levin College of Law, University of Florida, Gainesville, FL. Laura Minton, Attorney, Dean, Mead, Egerton, Bloodworth, Capouano, and Bozarth, Orlando, FL. Dulcy Miller, attorney, Foley and Lardner, LLP, Orlando, FL. Sarah Corbett, Attorney, Florida Second District Court of Appeal, Lakeland, FL.

The Institute of Food and Agricultural Sciences (IFAS) is an Equal Opportunity Institution authorized to provide research, educational information and other services only to individuals and institutions that function with non-discrimination with respect to race, creed, color, religion, age, disability, sex, sexual orientation, marital status, national origin, political opinions or affiliations. U.S. Department of Agriculture, Cooperative Extension Service, University of Florida, IFAS, Florida A. \& M. University Cooperative Extension Program, and Boards of County Commissioners Cooperating. Larry Arrington, Dean 
statutory authority to regulate water wells to the individual Water Management Districts (WMD), and therefore, the appropriate WMD should always be contacted before taking any action involving water wells. The statutes and rules are designed to safeguard both the quality of water extracted from the wells and the quality of the aquifer water, both of which could potentially be polluted by intruding wells.

\section{What Are the Well Construction Requirements?}

A "well" is defined basically as any excavation to acquire, locate, or artificially recharge groundwater. Under the statutes, the construction, repair, or abandonment of wells must be performed only by licensed contractors. The WMDs provide testing and other licensing procedures for contractors. There are, however, a few important exceptions to the requirement that a licensed contractor do the work, as long as the individual complies with all other local or state laws. No license is required for the following:

- For homeowners (or renters) to construct a well two inches or less in diameter on their property.

- The well is intended for use only in a single-family house which is the residence or is intended for use only for farming purposes on the farm, and the water to be used is not intended for use by the public or any residence other than his own.

- The homeowner (or renter) must also comply with all local and state rules and regulations for the actual construction of the well.

- In situations where the WMD determines that compliance with the rules would result in unnecessary hardship for the applicant.

To qualify for the undue hardship exemption, a written request must be made to the governing WMD. Regardless of exemption qualification, the DEP must be notified of a well once it comes into existence.

Construction of a well greater than two inches in diameter (such as a four-inch diameter well) must be performed only by licensed contractors. Homeowners constructing a well need to get a permit from their governing WMD as well as the DEP. Since permitting requirements vary among the five WMDs, homeowners should consult their governing WMD for its specific permitting requirements.

The construction, repair, or abandonment of a well will require a well permit from the appropriate WMD. The primary exceptions to this rule include the following:

- Construction permits need not be obtained retroactively for wells constructed before 1972 (although permits are required to repair or abandon these wells, and if the well is determined by the DEP to be a hazard to the groundwater resources).

- When one wants to temporarily operate equipment for dewatering.

- Where the district determines that requiring a permit would result in unnecessary hardship for the applicant.

- A permit is not required before construction, repair, or abandonment of any well exempted by Chapter 373, Florida Statutes, Sections 373.303(7) and 373.326.

Remember that the WMDs also require a consumptive use permit for many withdrawals or diversions of water regardless of applicable well permitting exemptions. Also, imprudent pesticide use near wells may result in contamination of groundwater in the underlying aquifer, causing widespread pollution. Consequently, farmers should be familiar with all regulations designed to prevent water contamination before taking any action involving water wells.

\section{Where Must a Well Be Placed?}

All proposed well sites must be pre-approved by the appropriate WMD. This protects against the possibility that a well will unknowingly be drilled into an area of existing groundwater contamination. The DEP provides continually updated maps of contaminated sections of the aquifer to the WMDs and pertinent county health departments. This 
information is available upon request to applicants. The WMDs and county health departments also prescribe the minimum distances from the contaminated areas in which wells may be constructed. The WMDs are also responsible for advising applicants on the minimum well placement distances from septic tanks, drain fields, chemical storage areas, and other potential pollution sources.

\section{What Are the Well Standards and Specifications?}

The DEP also publishes basic requirements for drilling techniques and materials, grouting and sealing, identification and labeling of well heads, and other highly specific areas. These standards must be observed even where it is not necessary to obtain a permit or license. Again, the WMD rules supplement DEP requirements and should be consulted.

\section{What Are the Well Permits and Fees?}

Each WMD sets permit application fees depending primarily upon the nature of the activity and the size of the well. The fees may be as little as $\$ 1$ for activities such as abandonment, but may not exceed $\$ 100$ for private residential wells or $\$ 500$ for public supply wells. No fee will be assessed for amendments of existing permits.

Construction permits are valid for a period of one year. If the construction or repair cannot be finished within one year, the WMDs have two options. The WMD can either extend the limit or require a new permit. Most WMDs require a consumptive use permit before a well construction permit will be approved. Some WMDs require an artificial recharge permit to put water into the ground. Some basic aspects of consumptive use permits, which are also regulated by the individual districts, are outlined in FE604, Consumptive Use Permits.

\section{What Are the Penalties}

The DEP, WMDs, or other governmental bodies may bring both civil and criminal penalties against violators of the statutes or rules. Constructing, repairing, or abandoning wells without a license or in violation of the other requirements is a second-degree misdemeanor punishable by a fine of up to $\$ 500$ and/or imprisonment for up to 60 days. Each agency is also authorized to bring civil suit for damages up to $\$ 10,000$ per violation. The WMDs also have the authority to impose administrative fines not to exceed $\$ 10,000$ for each offense.

\section{Source}

Chapter 373, Florida Statutes, Sections 302 to 342; Chapter 62, Florida Administrative Code, Section 531 to 532; Title 40, Florida Administrative Code

\section{Contact Information}

Water Well Regulations (FE616, Contact Agencies)

- S-1, Florida Water Management Districts

- F-2, RCRA/CERCLA (Superfund) Hotline

- L-3, Groundwater Section

\section{Acknowledgments}

The authors are indebted to the personnel of both state and federal agencies who provided their time and advice in the preparation of this handbook. The authors are especially indebted to Richard Budell of the Office of Agricultural Water Policy of the Florida Department of Agriculture and Consumer Services for providing funds for the development of this publication. 